\title{
21 世紀を担う学生たちへ
}

キーワード

研究，諭文，教科書，アナログ回路

\author{
正員高木茂孝 \\ 東京工業大学
}

\section{1. まえがき}

「21 世紀の罪」は今開き始めたばかりである.「21 世紀 の扉」を大きく開き，輝かしい未来を実現するに渃い力 が必要である．近年叫ばれている少子化や理工系離れのた め工学の分野を志す㯪秀な人材が減少してきている. IT 革 命と馶がれる中で，筆者が関わる回路工学の分野は IT 革 命を支える裏方であり，アナログ回路となるとさらに地味 な分野との印象を否めない，

このような状況において，筆者の研究室等に所属を希望 し，裹方的分野のアナログ回路の研究を志す学生は希有な 感性を有する者たちであり，筆者にとっても社会にとって も貴重な存在である．本稿では，このような若者たちと接 して筆者が日頃感じていること，現代の学生たちが己の能 力を十分に発揮するためにすべきこと，学生たちにして欲 しいことについて述べてみたい.

\section{2. 計算機世代}

現代の若者はコンピュータが大好きである．計算機の前 ならば何時間でも座っていられるが，これが勉強机の前と なると 30 分ももたないのではないだろうか。これに対し て筆者は「計算機の前に座っている者は研究をしていない.」 と学生たちに言い続けている. 彼らは計算機を使って回路 シミュレーションプログラムと格䦙することが研究である と信じているようである。私自身にも経験があるが，計算 機と格䦥すると, あっと言う間に数時間が過ぎ, 研究をした という感覚を味わうことができる.だが，果たして本当に 研究をしていたのであろうか. 学生たちが回路シミュレー ションプログラムを使う場合、素子の値を無闇やらたと変 え, 得られた結果の中で一番良いものを選び出すという作 業をしており, 素子の値の選び方に理屈は無い. 最近, 計 算機のスピードが恐ろしい勢いで增し，複雑な計算も瞬時 の内に済ませてくれる，当てずっぼうで素子の值を変えて も，時間を気にしなけ扎ば，何とか良い結果に辿り着く甘 組みになっているようである.

学生たちのやり方に類する力ずくの研究も見かけるが, このような計算機の使い方で良いのであろうか. 1920 年代 に始まった回路網の合成理論は，1930 年代，40 年代を経

To Students Who Should Create Technologies in the 21st Century. By Shigetaka Takagi. Member (Tokoy Institute of Technology)
て 50 年代にほぼ完成している. 第 2 次世界大戦中やその後 の物や金の無い時代にもかかわらす，日本でも多くの方々 が世界的に一級の研究をなされている. 推測に過ぎないが， 今のような回路搼造や素子值を与えるとあっと言う間に特 性が求められるという睘境ではなかったからこそ，紙と鈶 筆を使って地道に回路やその特性を求めようとされていた からこそ，すばらしい研究成果を挙けられたのではないだ ろうか。

計算機はあくまでも道具であり，人が適切な指示を与え て使う機械である．使う人の考えが反映されないような使 い方は誤っている，学生たちには，自分のアイティアを紙 と鈶筆（最近はシャープペンシル）を使って，しっかりと計 算し，その正当性を様々な角度から確認し，確認の方法の 一つとして計算機を使って䚿しい，紙と鉿筆を使って計算 することにより，物事の本質が見えてくるはずである.自 分のアイティアに関する見通しや確信を持たずに，計算機 を使うことは時間の浪費である．計算機はあくまで確認の ための道具である、紙と鈶筆から新しい回路は生まれるが， 計算機は回路を生み出してはくれない.

\section{3. 論文・教科書信仰}

我々の研究室では，ゼミにおいて外国の雑誌に揭載され た論文を学生が紹介することがある，学生が紹介した論文 について，どうしてそういう結果に至ったのかと尋ねると， 理由は答えず,「結果だけが諭文に書いてありました.」とい う回答が返ってくることがある. 学生にしてみると, 論文 には最先端のすばらしい研究成果が書かれていると思って おり,しかも高名な先生が名前を連ねていると, 誤りなど あるはずがないと信じているのであろう。ただ、これは論 文を盲信しているに過ぎない，

自分自身が論文を書いた立場からすれば，当然誤りの無 いように論文を仕上げたつもりではあるが，添え字のミス など，後から気づくことも多い，もちろん，敕正な査読を 経て揭載に至った諭文であるから，本質的な誤りがあるこ とは滅多にないが，疑ってみることも重要である．信じる ことは容易であるが，疑うことは労力を伴う．疑うために は、論文の道筋を追わなければならず，再び紙之制筆の登 場である．残念ながら，論文の著者たちが経験した創造の 苦しみを味わうことはできないが，疑うことによりその分 野において論文と同等のレベルに到達できるのである。 
大学で用いる教科書についても同じことが言える. 高校 までの教科書は間違いが無く, このことが学生に教科書や 論文を疑わせることを妨げている一因になっているのでは ないだろうか，逆説的ではあるが，誤りの多い教科書は読 者を育てる良書である. 学生たちには常に疑う気持ちを持っ ていて欲しい. さらに，疑わしいと思ったら必ず確認を怠ら ないで欲しい．人格的にはいただけない話ではあるが，研 究に携わる者としては必要な要件である.

\section{4. 流行語の誘惑}

アナログ回路の分野では,「電流モード」回路が一種のブー ムである. ディジタル回路とともにアナログ回路の電源電 圧も徐々に低下している. このため, 電圧を信号として用 いていたのでは, 信号振幅が大きく制限される.この問題 点を解決するために登場したのが「電流モード」回路であ る. 電流を信号として用いれば, 電源電圧に制限されるこ となく, 電圧信号よりも大きな信号振幅が期待できる. 研 究成果の提出が目前に迫っている修士 2 年生や博士課程の 学生にとっては「電流モード」とは魅力的な響きを持つ言 葉である.

ゼミにおいて, ある学生が「電流モード」回路について 発表したとき,「電流モードって何？」と尋ねてみた，する とその学生は「入力信号と出力信号がともに電流である回 路です.」と答えた.ももともそうな回答であるが，果たし てそれで良いのであろうか.「電圧モード」回路の入力に電 流-電圧変換器を接続し, 出力に電圧-電流変換器を接続す れば「電圧モード」回路が「電流モード」回路に早変わり するのであろうか.これは,「電流モード」の本質を見失つ たために起きた誤りである，論文を樢吞みにし，単に外見 のみを模做したに過ぎず,「電流モード」の果たすべき役割 を理解できていないため,「電流モード」という言葉を正確 に定義できないのである.

脱楾になるが，たぬきそばには「たぬき」が入っている ことをご存知だろうか．たぬきそばに入っている揚げ玉は 「たねがぬかれている」ことから，揚げ玉を「た（ね）ぬき」 と酒落て，ためきそばの名前がついたという説がある. た ぬきそばというネーミングは一見めちゃくちゃに思えるが, 本質が理解できれば納得のいく定義である. 本質を持たな い定義は無意味であり，本質を理解していない言葉の乱用 は危険である。

\section{5. 哲学とは?}

ゼミにおける議論の最中に, 教官から「それは本当なの?」 と言われると即座に前言を撤回する学生がいる．論文には 誤りが無いと信じているのと同じように, 日頃指導して貪つ ている教官の言うことに間違いは無いと信じているのであ ろうか. 学生が間違っている場合がしばしばであるが, 教 官とても誤りはある．前言を撤回する前に教官が「それは 本当なの?」と尋ねた意味を良く考えて欲しい。「良く考え る」ということは自分の発表内容に矛盾がないか, 教官が
疑問を頂く理由は何かを考えるということである．特に博 士の学位を目指す学生ならばなおさら良く考えて欲しい. 「博士号を英訳すれば，Doctor of Philosophyであり，哲 学博士のことである. だから，博士号を志す者は自分の哲 学を持たねばならない.」という話を人づてに聞いたことが ある. 論理の飛羅はさておき,この発言は「博士号を志す者 は自分の研究スタイルを持ちなさい. 自分の研究スタイル を持ってこそ博士として認められるのですよ.」ということ を Doctor of Philosopy という言葉を引き合いに出して訴 えているのである. 発表した内容を教官の一言により，良 く考えもせずに即座に撤回するということは, その学生が 自分の発表内容を論理的に理解していない, あるいは表面 のみの理解でとどまっているためであろう. 博士課程の学 生であれば教官から「それは本当なの?」と言われたとき, 教官を説得する気概があって欲しい.「本当か？」と訊かれ， 「本当です!」と返すような, 教官とのやりとりの中から自 分の研究スタイルが生まれてくるのではないだろうか. 博 士課程の学生が, 自らの研究スタイルを確立し, 立派な研 究成果を上げ, 研究室から巣立っていくことを希望する.

\section{6. むすび}

ここで述べた事柄は筆者の体験からの反省を含んでおり, 「学生」がときには著者自身であったりもする．自分自身の 体験や教官として学生と接した経験が, 少しでも学生諸君 の役に立てばと思い, 筆を取った. 学生諸君には, 日頃か ら紙と鈶筆を使い，良く物事を考えるという努力を続けて 欲しい. 自分のアイティアが間違っていることに気づくこ とや既に発表されていたアイディアであったなどというこ とはよくあることである.このようなことに挫けず，努力 を続けられる人が研究者にふさわしいのではないかと最近 強く感じる. アイディアが出尽くしたと思った後, 本当に 良い知恵は生まれてくるものである．時には羽を伸ばすこ とも必要かと思うが, 努力を忠ってはならない、「21 世紀の 扉」は今開き始めたばかりであり,「21 世紀の扉」を大きく 開き, 輝かしい未来を実現するためには若い力が必要なの だから.

(平成 12 年 8 月 31 日受付)

高木茂（正員）昭 56 東工大·工・車気電子卒。昭 61 同 大大学院博士課程了。工博。同年同大.工・助手。 現在, 東工大・集積システム専攻・助教授。平 10 年度大阪大客員助教授。電子情報通信学会昭 63 年度篟原記念学術势励賞, 平 7 年度論文賞を各受 筫。アナロク集稍回路の研究に従事。著書「MOS アナロク電子回路」(昭晃堂)、「デダタル集稙 回路入門」(共著, 昭晃堂)。電子情報通信学会, 